\title{
Ofício de Criança / Childhood as an Occupation
}

https://doi.org/10.21814/uminho.ed.36.47

Régine Sirota

Université Paris Descartes, France 



\section{Ofício de Criança}

A expressão "ofício de criança" representa a entrada da criança no cenário sociológico, fruto de um mar de mudanças que buscou resgatar a infância da sua invisibilidade sociológica, olhando com seriedade para esta fase da vida e as experiências sociais que ela experimenta. Ao atribuir às crianças um "ofício", esta expressão é também um dispositivo estilístico, visto que oximoronicamente contrasta e combina dois conceitos aparentemente contraditórios. "O ofício de uma criança" refere-se a uma função social que geralmente é considerada competência de adultos (por exemplo, ocupação, atividade profissional ou trabalho) e que fornece aos adultos reconhecimento social, bem como sustento económico; no entanto, também se refere implicitamente à noção de inocência que ostensivamente protege as crianças do espectro crescente do trabalho. Graças a essa oposição, a expressão destaca as obrigações sociais e o estatuto que a sociedade atribui à infância. Ao fazê-lo, também reconhece a produtividade do trabalho social realizado pelas crianças. Diversas mudanças na esfera académica contribuíram para esse desenvolvimento: o reconhecimento do papel desempenhado pelas crianças na divisão do trabalho; o reconhecimento do trabalho doméstico dentro da unidade familiar de forma mais ampla; e, por outro lado, o reconhecimento das crianças como atores sociais de pleno direito nas várias esferas de socialização governadas pela escola ou pela família. Rompendo com uma conceção excessivamente socializada de infância, em que a criança é considerada apenas um objeto passivo de socialização, essa nova perspetiva vê a criança como um verdadeiro parceiro nas interações sociais. Ele enfatiza a dimensão ativa da infância, ou o que os sociólogos de língua inglesa chamam de "agência". Mas também insiste no contexto social e na função atribuída à infância - ou seja, a capacidade das crianças de criar uma identidade tanto no presente (de acordo com as exigências do seu estádio de vida atual) e no futuro. As crianças são, portanto, vistas como pessoas competentes, "seres reais" que vivem no presente. Elas são entendidas como produtos e produtoras de acordo com uma construção social que estabelece normas e requisitos sociais em termos de comportamento, em última análise, moldando a ocupação que irão desempenhar. Por outro lado, no entanto, esta ocupação é também um espaço de improvisação contínua que requer saber-fazer prático e competências sociais, bem como compreensão e controlo de uma dada situação. 
Enquanto a expressão métier d'enfant se tornou bastante difundida na pesquisa de língua francesa e seu equivalente em português "ofício da criança" também ganhou força, o conceito permanece relativamente desconhecido nos estudos anglófonos, visto que as nuances linguísticas da palavra métier (ou "ofício") são difíceis de apreender em inglês. Além disso, os obstáculos enfrentados pela tradução refletem o peso das respetivas tradições sociológicas e as diferentes origens do conceito.

No reino da sociologia francesa, Jean-Claude Chamboredon e Jean Prévost foram os primeiros a introduzir o métier d'enfant, ou a ocupação infantil, usando a expressão cunhada por Pauline Kergomard, uma famosa educadora francesa e inspetora de jardins de infância. Para Kergomard, brincar é o trabalho infantil e as atividades no jardim de infância devem permitir que as crianças se desenvolvam por meio da brincadeira, criando e fortalecendo suas competências sociais e habilidades, sejam elas físicas, intelectuais ou morais. No contexto da sociologia da reprodução social, embora a expressão destaque a importância da primeira infância no processo de socialização, ela também chama imediatamente a atenção para as desigualdades que podem influenciar os resultados futuros da infância. Por detrás de uma expressão genérica, então, podemos vislumbrar diferenças em termos de classe, etnia, género, etc.

De um ponto de vista mais interacionista, a expressão "ofício de criança" pode ser usada e aplicada diretamente ao ambiente escolar, em particular ao enfatizar o papel de "intermediário" que as crianças desempenham nas instâncias de socialização. Também nos permite descrever as várias estratégias utilizadas pelas crianças para enfrentar as situações, no contexto de interações que combinam elementos materiais, simbólicos e humanos. Nesse caso, aproximamo-nos do conceito de reprodução interpretativa, mais comummente encontrado em pesquisas de língua inglesa. Na esfera familiar, o ofício de criança é formado por meio da interação, e em paralelo, com o ofício parental (o papel de ser pai/mãe); da mesma forma, num ambiente escolar, o ofício de aluno desenvolve-se em relação ao papel desempenhado pelos educadores/professores. Para exercer o seu ofício, as crianças devem, portanto, navegar em várias áreas de socialização que se cruzam.

Isso significa que devemos considerar a multiplicidade de experiências sociais da infância para entender como elas se desenvolvem em cada esfera, mas também como se cruzam em diferentes domínios de socialização - família, escola, grupos de pares, media, trabalho, consumo - inclusive em amplos e diversos contextos sócio históricos e socioculturais. Desempenhar 
a "infância como ofício" também pode produzir diferentes condições e, portanto, modelos de infância, que atribuem peso variável às diferentes esferas de socialização. Obviamente, também devemos levar em conta os efeitos geracionais para entender como os diferentes estágios da infância foram transformados e conectados. A individualidade de uma criança e os seus laços sociais são criados por meio das experiências diárias da criança no seu ofício.

\section{Childhood as an Occupation}

The expression "a child's occupation" or métier d'enfant represents the arrival of the child on the sociological scene, the result of a complete change that sought to rescue childhood from its sociological invisibility by taking a serious look at this stage of life and the social experiences it engenders. By attributing an "occupation" to children, this expression is also a stylistic device, given that it is an oxymoron which both contrasts and combines two apparently contradictory concepts. "A child's occupation" refers to a social function that is generally considered to be the scope of adults (e.g., occupation, professional activity or work) and which provides adults with social recognition as well as economic livelihood; however, it also implicitly refers to the notion of innocence that ostensibly protects children from the looming spectre of work. Thanks to this paradox, the expression highlights the social obligations and status that our society attributes to childhood. In doing so, it also recognizes the productivity of the social work done by children. Several changes in the academic sphere have contributed to this development: the recognition of the role played by children in the division of labour; the recognition of domestic labour more broadly within the family unit; and on the other hand, the recognition of children as fully-fledged social actors in the various realms of socialization governed by school or the family. Breaking with an over-socialized conception of childhood, in which the child is considered to be merely a passive object of socialization, those who accept this new perspective view the child as a true partner in social interactions. It emphasizes the active dimension of childhood, or what English-language sociologists term "agency". But it also insists on the social context and function attributed to childhood - that is, children's ability to create an identity both in the present (according to the demands of their current life stage) and in the future. Children are therefore seen as competent persons, "actual beings" living in the present. They are understood to be both products and producers according to a social construct which establishes social norms and requirements in terms of behaviour, 
ultimately shaping their future occupation. On the other hand, however, this occupation is also a space of continuous improvisation that requires practical capability and soft skills, as well as comprehension and control of a given situation.

While the expression métier d'enfant has become fairly widespread in French-language research and its Portuguese equivalent "ofício da criança" has also gained traction, the concept remains relatively unknown in Anglophone studies, given that the linguistic nuances of the word métier (or ofício) are difficult to capture in English. The obstacles facing translation, moreover, reflect the weight of respective sociological traditions and the different origins of the concept.

In the realm of French sociology, Jean-Claude Chamboredon and Jean Prévost were the first to introduce the métier d'enfant, or the child's occupation by using the expression coined by Pauline Kergomard, a famous French educator and kindergarten inspector. For Kergomard, play is the child's labour and kindergarten classes must allow children to develop through play, creating and strengthening their social skills and abilities, be they physical, intellectual or moral. In the context of reproductive sociology, while the expression does highlight the importance of early childhood in the socialization process, it also immediately draws attention to inequalities that can determine childhood outcomes. Behind a generic expression then, we can glimpse differences in terms of class, ethnicity, gender, etc.

From a more interactionist standpoint, the expression "a child's occupation" can be used and directly applied to the school setting, in particular by emphasizing the role of "go-between" that children perform in instances of socialization. It also allows us to describe the various strategies used by children to cope with situations, when interactions combine material, symbolic and human elements. In this case, we draw closer to the concept of interpretive reproduction, more commonly found in English-language research. In the family sphere, the child's occupation is formed through interaction with, and in parallel to, the parental occupation (the role of being a parent); similarly, in a school setting, the student's occupation develops in relation to the role performed by educators. In order to perform their occupation as children, children must therefore navigate multiple intersecting areas of socialization.

This means that we must take into account not only the multiplicity of social experiences of childhood in order to understand how they are 
developed in each sphere, but also how they intersect across different realms of socialization - the family, school, peer groups, the media, work, consumption - including vastly different sociohistorical and sociocultural contexts. Accepting "childhood as an occupation" can also engender different conditions and thus models of childhood, which grant variable weight to the different realms of socialization. Of course, we must also account for generational effects to understand how the different stages of childhood have been transformed and connected. A child's individuality and his or her associated social ties are created through the child's everyday experiences of his or her occupation.

\section{Referências / References}

Chamboredon J-C. \& Prévot, J. (1973). Le «métier d'enfant» définition sociale de la prime enfance et fonctions différentielles de l'école maternelle. Revue Française de Sociologie, XIV(3), 295-335. Réédité in Chamboredon J.-C. (2015). édition de Paul Pasquali, Jeunesse et classes sociales. Paris : Editions Rue d'Ulm.

Chamboredon J-C. \& Prévot, J. (1975). Infancy as an occupation. Towards a Sociology of Spontaneous Behaviour. Paris: OECD.

Sarmento, M. (2011). A reinvenção do ofício de criança e de aluno. Atos de pesquisa em educação, 6(3), 581-602.

Sirota, R. (1998). Lémergence d'une sociologie de l'enfance, évolution de l'objet, évolution du regard. Education et Sociétés, 2, 9-33.

Sirota, R. (2001). Emergência de uma sociologia da infância: evolução do objeto e do olhar. Cadernos de pesquisa, 112, 7-31. 